\title{
Asean Is Working On The Triple-Cs Principle For Regional Economic Integration
}

\author{
Dr. Sarfraz Batool' ${ }^{1}$, Sadia Mahwish ${ }^{2}$, Dawood Nawaz ${ }^{3}$, Husni Mubarak ${ }^{4}$ \\ ${ }^{1}$ Assistant Professor at Department of Political Science, The Islamia University of Bahawalpur, Pakistan \\ ${ }^{2}$ Lecturer at Department of Economics, Government Sadiq College Women University Bahawalpur, Pakistan \\ ${ }^{3}$ Associate Lecturer (Public Administration) at Department of Political Science, The Islamia University of Bahawalpur, Pakistan \\ ${ }^{4}$ Associate Lecturer at Department of Political Science, The Islamia University of Bahawalpur, Pakistan \\ ${ }^{1}$ sarfraz.batool@iub.edu.pk, ${ }^{2}$ sadia.mahwish@gscwu.edu.pk, ${ }^{3}$ dawood.nawaz@iub.edu.pk
}

\begin{abstract}
Southeast Asian Association for regional Co-operation was established in 1967 for the region's socio-economic development. Now it has been working as a single economic body and has become the sixth-largest economy in the world and third largest in Asia. It constitutes the thirdlargest population in the world that is effectively connected through physical and digital means. This study aims to develop a theoretical understanding of the concept of regional Integration and to analyze the trends of regional integration suitable for the South East Asian region specifically. It focuses on the ASEAN's Triple-Cs Principle to deeply analyze its journey of regional economic integration. This Principle, basically, describe the existing strategic patterns of economic integration specifically used in the ASEAN countries to maintain their territorial integrity and increase socio-economic development in the world's most diverse region. It further shows that how ASEAN remained consistently committed to regional integration since its initiation, for that purpose, how ASEAN worked on the journey of regional connectivity. And, How the advancement in the digital arena, is constantly increasing the regional connectivity (through digital means) and has become a backbone for the process of regional integration in the Asian region. Finally, how regional connectivity brings Peace, Progress, and Prosperity in the South East Asia. Further, it also helps to analyze that how much the existing patterns of Asian regionalism are conducive for socio-economic development. This study is divided into the following sections; the first section briefly describes the central theories of regionalism. In addition, it extensively describes the concept of region, regionalism, and regional integration and the importance of regional integration in the Asian region. The second section of the study explains the details of the Triple-Cs Principle of ASEAN for regional integration. The third section describes how ASEAN followed the Triple-Cs principle during its journey towards regional economic integration in different phases. Finally, it concludes with certain recommendations
\end{abstract}

Keywords

Regional Integration, Regionalism, Functionalism, Federalism, Triple-Cs, ASEAN, Regional Development, Socio-economic development. MPAC

Article Received: 10 August 2020, Revised: 25 October 2020, Accepted: 18 November 2020

\section{Theoretical Concept of Regionalism}

The concept of regionalism is multidimensional in its very nature. For instance, some theorists consider that peace and security is the key factor behind regional cooperation/regionalism, while other emphasize on political and economic reasons for regional cooperation. However, inter-state economic and cultural co-operation is very significant for the promotion of peace and security in the region because it enhances unity among the politically and culturally diversified communities of states. In-fact economic development and regional peace and security go hand in hand. That is why the terms of the agreements which are decided for the integration of the states could be economic and political in nature. Many scholars define different theories about regionalism mostly based on European integration-federalism is one of them. Instead of a theory, federalism was most near to a political program which was in favor of the creation of new kind of state. The second theory is functionalism which emphasis on the question that at which level a political system can best satisfy the human needs? It prescribed to go beyond nationstate but it is not necessary to be regional.

The third point of view is the most celebrated by the scholars because it theorized the 'community method'. The
'European Community' (EC) was established on this model. The basic mechanism for this method was 'spillover' and the result could be a federation which was not building on the constitutional designs. This concept is defined as "the way in which the creation and deepening of integration in one economic sector would create pressures for further economic integration within and beyond that sector and enhance authoritative capacity at the European level. A free trade area would lead to a customs union and further to the establishment of a common market, economic union and political union" (Soderbaum, 2011).

In 1960s, another perception of integration was presented by Stanley Hoffman in which security is defined in the sphere of high politics and economics is in the sphere of low politics, and Stanley Hoffman believed that integration would spread from low politics to high politics and image of the 'European Community' began to diverge (Soderbaum, 2011). The developments of 1985 (White Paper on internal market and Single European Act) brought a dynamic change in the concept of regionalism on a global scale. The end of Cold War also resulted in the surge of regionalism and the trends of more and deeper regionalism evolved (Brozel, 2016). The new perspectives on regionalism include the trends of globalization and often considered as 'new regionalism'. Further studies especially in 1990s have generated a huge variety of the concepts regarding 
regionalism. Especially after the end of the cold war, the rise of regionalism in the world not merely based on regional cooperation (mainly trade agreements) but also emphasized the broadening and deepening of the existing trends of regionalism.

Further, the latest studies focused more to develop strategies which can help to create and deepen the practices of integration in the Asian region because Asian regionalism is very crucial for the development of the whole region. This variety of concepts certainly provide different basis for the current regionalization trends. "The current regionalization could be seen as a new political landscape in the making, characterized by an expanding cast of actors (state and nonstate) operating in the regional arena and across several interrelated dimensions like security, trade, development, identity, environment and so on" (Soderbaum, 2011). The global trends of the integration models also create many variations. So, mostly the researchers based their researches on the European experiences of regional integration. However, the later studies and researches emphasized the Western approaches of regional integration and experienced the successful regional integration of North America. Therefore, diversity of theories is a must result, while the diversity of the Asian region also increases the varieties of integration.

Despite the diversity, the neo-functionalism approach is the most influential one. Its mechanism basically works on the 'spillover' effect. It is a way of integration in which the economic integration of one sector persuades for the economic integration of more related sectors. This approach is dominating at the regional level as well as the global level because the revolution in IT sector multiplies this spillover effect in the world. This study is helpful to understand that how we can foster the process of integration in Asian region. It is also helpful to understand that how to avoid the conflicting situations of diversity of Asian region.

The concept of Asian regionalism is dominated with the researches of ASEAN because it considered a successful regional organization outside Europe which maintains its survival for a long time. Asia is the only region in the world where a security institution had been established at the macro-regional level after the end of Cold war. It simply clarifies the intra-regional tussles and disturbed peace and security situations in Asia. More specifically, after the World War-II, the significance of Asian regionalism and integration had been realized and since then there are three main institutions that promote regional co-operation in South East Asia. These institutions are United Nations; GMS (Greater Mekong Sub-region) a program by ADB and third is ASEAN. (UNDP, 2006). Among all these, ASEAN is the most dominating in debates even during and after the Cold War period. As Kahler writes, 'given the short and less than-useful lives of many regional organizations in the developing world, ASEAN is unusual, not only for its longevity, but also for its flexibility in serving the purposes of its members' (Kahler, 1994). Acharaya and Johntson's approach is also more focused on the Asian region and is able to account for the 'ASEAN way'. Acharaya's approach is based on the 'informality, flexibility, consensus and nonconfrontation' (Soderbaum, 2011).

\section{Concept of Region, Regionalism and Regional Integration}

The word region is originated from the Latin word region which means 'to rule'. Later this word was borrowed for the definition of a formal sub-national entity and many other countries used it conventionally as the name of a subnational administrative unit as well. The term region defined in the dictionary as 'an area may be part of a country or the world which have some known features but the boundaries may not be fixed always'. The geographical explanations define regions as the 'divided areas by their physical characteristics, environment, human impact and interaction of humanity'. The concept of region when politically defined then it tends to be based on the political units such as the sovereign states or sometimes as sub-national units such as administrative regions and multinational clusters (including formal (EU, ASEAN and NATO) and informal (third World, Western Europe and Middle East) groupings). WTO's definition of region also includes the bilateral economic or trade accord which is not global and multilateral. A Preferential Trade Agreement (PTA) between Israel and Singapore also constitute a regional trade agreement. Brozel and Risse develop an understanding about region and called it 'social constructions that make references to territorial location and to geographical or normative contiguity.' (Brozel, 2016) The above-mentioned definitions define the sphere of regions as continental, subcontinental, transcontinental. In modern times, WTO defines the bilateral trade agreements of even non-contiguous states as regional accord.

Brozel and Risse defined that, regions can be a group of limited number of interlinked states by a geographical relationship and by a degree of mutual interdependence and regionalism refers to the intensifying political and economic processes of co-operation among states. They further explain the regional integration as a process which begins when states transfer at least some authorities and sovereignty rights to the regional level (Brozel, 2016). In addition to this, dimensions of the regionalism could be political, economic, security and identity based. That is why Fredrick Soderbaum defines regionalism, "as the policy and project or the cognitive idea of forming regions and regionalization as the process of co-operation, integration, cohesion and identity creating a regional space (issuespecific or general). And both regionalism and regionalization may involve state as well as non-state actors" (Soderbaum, 2011). In the perspective of Asian region, a mixed approach is necessary for the strength of integration process in Asian region.

It is easy to assess that in the modern times, any economic and political collaboration can create a region and when some of the authorities transferred to regions then the integration process initiated. The economic development of the modern states is mostly associated with the regionalism. The trends of regionalism made it a dynamic topic of discussion in the academic field. The economic development of modern state is used as a tool to measure the potential of a state to grow.

Scholars of the time tried to reduce the tensions of the Asian region, so, it could foster the process of regionalism in the South East Asia because it is helpful for the attainment of 
the sustainable goals of development. Many researchers of the international relations have explored the positive effects of regionalism and consider it helpful to foster peace, security and stability in the region. It is also helpful to strengthen democracy, human rights, regulate migration and to curb environmental pollution (Brozel, 2016). All these effects are developmental goals to achieve in the Asian region. So, an approach of mixed trends of regional integration must be encouraged and practiced in Asian region. However, many experts on the South East Asian studies considered that to get benefits from regional integration ASEAN members must satisfied many conditions.

Political willingness and commitment of all countries, inclusion of rich states and adoption of higher forms of integration, mutual economic dependence, narrow down the intra-regional economic gaps or disparities, commonalities at policy level and finally good governance in institutional framework is crucial to get larger benefits from economic integration. (UNDP, 2006). According to the researches of many scholars, ASEAN is the sole organization which is working for the integration of region and maintains its survival as well. Scholars argued that, states that have distinct systems but stood the at same stage of development and integrated themselves because of their common goals can have better opportunities to grow (McVey, 1995) (Phan Thanh Chung, 2019). Because by taking coactions on the issues that transcend national territorial limits, states have opportunity to enhance their prospects regarding development and can boost their capacities to reduce poverty, to encourage peace and security in states and can make efforts to achieve sustainable development. And when scholars talk about the Asian regionalism, they specifically mention the 'ASEAN Way' or 'soft institutionalism' (Tekunan, 2014) (Stone, 2018) (Park, 2017).

Actually, 'ASEAN Way' is an official national anthem of ASEAN and it represents the ideology of soft institutionalism which mainly consists on the norms of discreetness, informality, pragmatism, consensus-building and non-confrontational bargaining style (Guan, 2004) (Acharaya, 2007) (Tan, 2019). The experts of Asian regionalism support the informal structures of organization because it ensures the sustainability of organization (ADB, 2020) (Acharaya, 2004) (Guan, 2004). This paper describes that the Triple-Cs principle can accommodate the diversity (see table below) of the region in effective way and helps to find the 'unity in diversity' in the world's most diversified region.

Table 1: Political, Economic and Ethnic Diversity of ASEAN Member Countries

\begin{tabular}{|c|c|c|c|c|c|c|}
\hline $\begin{array}{l}\text { Cou } \\
\text { ntry } \\
\text { Na } \\
\text { me }\end{array}$ & $\begin{array}{l}\text { Inde } \\
\text { pend } \\
\text { ence }\end{array}$ & $\begin{array}{l}\text { Colo } \\
\text { nial } \\
\text { Hist } \\
\text { ory }\end{array}$ & $\begin{array}{l}\text { Politic } \\
\text { al } \\
\text { System }\end{array}$ & $\begin{array}{l}\text { Econ } \\
\text { omic } \\
\text { Syste } \\
\text { m }\end{array}$ & $\begin{array}{l}\text { Secu } \\
\text { rity } \\
\text { Issue } \\
\text { s }\end{array}$ & $\begin{array}{l}\text { Ethn } \\
\text { ic } \\
\text { Dive } \\
\text { rsity }\end{array}$ \\
\hline $\begin{array}{l}\text { Ind } \\
\text { ones } \\
\text { ia }\end{array}$ & $\begin{array}{l}7 \\
\text { Aug, } \\
1945\end{array}$ & $\begin{array}{l}\text { Dutc } \\
\mathrm{h}\end{array}$ & $\begin{array}{l}\text { Unitary } \\
\text { Preside } \\
\text { ntial } \\
\text { Constit } \\
\text { utional } \\
\text { Republ } \\
\text { ic }\end{array}$ & $\begin{array}{l}\text { Mixe } \\
\text { d } \\
\text { Econ } \\
\text { omy }\end{array}$ & $\begin{array}{l}\text { Local } \\
\text { insur } \\
\text { genci } \\
\text { es } \\
\text { and } \\
\text { separ } \\
\text { atist } \\
\text { move }\end{array}$ & $\begin{array}{l}86.7 \\
\% \\
\text { Musl } \\
\text { ims } \\
\text { (over } \\
300 \\
\text { ethni } \\
\text { c }\end{array}$ \\
\hline
\end{tabular}

\begin{tabular}{|c|c|c|c|c|c|c|}
\hline & & & & & ments & $\begin{array}{l}\text { grou } \\
\text { ps } \\
\text { over } \\
700 \\
\text { langu } \\
\text { ages) }\end{array}$ \\
\hline $\begin{array}{l}\text { Mal } \\
\text { aysi } \\
\text { a }\end{array}$ & $\begin{array}{l}31 \\
\text { Aug, } \\
1957\end{array}$ & UK & $\begin{array}{l}\text { Federal } \\
\text { Parlia } \\
\text { mentar } \\
\text { y } \\
\text { Constit } \\
\text { utional } \\
\text { Electiv } \\
\text { e } \\
\text { Monar } \\
\text { chy }\end{array}$ & $\begin{array}{l}\text { Newl } \\
\text { y } \\
\text { Indus } \\
\text { trializ } \\
\text { ed } \\
\text { Mark } \\
\text { et } \\
\text { Econ } \\
\text { omy }\end{array}$ & $\begin{array}{l}\begin{array}{l}\text { Bord } \\
\text { er }\end{array} \\
\text { issues } \\
\text { with } \\
\text { China } \\
\text { Singa } \\
\text { pore } \\
\text { and } \\
\text { Philip } \\
\text { pines }\end{array}$ & $\begin{array}{l}68.8 \\
\% \\
\text { Bumi } \\
\text { puter } \\
\text { a } \\
\text { (alm } \\
\text { ost } \\
\text { over } \\
10 \\
\text { ethni } \\
\text { c } \\
\text { grou } \\
\text { ps) }\end{array}$ \\
\hline $\begin{array}{l}\text { Sing } \\
\text { apo } \\
\text { re }\end{array}$ & 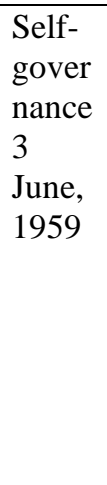 & $\begin{array}{l}\text { UK } \\
\text { and } \\
\text { Mala } \\
\text { ysia }\end{array}$ & $\begin{array}{l}\text { Unitary } \\
\text { Domin } \\
\text { ant } \\
\text { Party } \\
\text { Parlia } \\
\text { mentar } \\
\text { y } \\
\text { Constit } \\
\text { utional } \\
\text { Republ } \\
\text { ic }\end{array}$ & $\begin{array}{l}\text { Highl } \\
\text { y } \\
\text { Devel } \\
\text { oped } \\
\text { Mark } \\
\text { et } \\
\text { Econ } \\
\text { omy }\end{array}$ & $\begin{array}{l}\text { Wate } \\
\mathrm{r} \\
\text { issue } \\
\text { with } \\
\text { Mala } \\
\text { ysia } \\
\& \\
\text { Indon } \\
\text { esia }\end{array}$ & $\begin{array}{l}\text { Chin } \\
\text { ese } \\
74 \% \\
\text { (alm } \\
\text { ost } \\
15 \\
\text { ethno } \\
- \\
\text { religi } \\
\text { ous } \\
\text { grou } \\
\text { ps) }\end{array}$ \\
\hline $\begin{array}{l}\text { Phil } \\
\text { ippi } \\
\text { nes }\end{array}$ & $\begin{array}{l}4 \\
\text { July, } \\
1946\end{array}$ & USA & $\begin{array}{l}\text { Unitary } \\
\text { Preside } \\
\text { ntial } \\
\text { Constit } \\
\text { utional } \\
\text { Republ } \\
\text { ic }\end{array}$ & $\begin{array}{l}\text { Indus } \\
\text { trializ } \\
\text { ed } \\
\text { Econ } \\
\text { omy }\end{array}$ & $\begin{array}{l}\text { Area } \\
\text { claim } \\
\text { ed by } \\
\text { China }\end{array}$ & $\begin{array}{l}33.7 \\
\% \\
\text { Visa } \\
\text { yan. } \\
\text { More } \\
\text { than } \\
175 \\
\text { ethno } \\
- \\
\text { lingu } \\
\text { istic } \\
\text { grou } \\
\text { ps }\end{array}$ \\
\hline $\begin{array}{l}\text { Tha } \\
\text { ilan } \\
\text { d }\end{array}$ & $\begin{array}{l}24 \\
\text { June, } \\
1932\end{array}$ & $\begin{array}{l}\text { King } \\
\text { dom }\end{array}$ & $\begin{array}{l}\text { Unitary } \\
\text { Parlia } \\
\text { mentar } \\
\text { y } \\
\text { Constit } \\
\text { utional } \\
\text { Monar } \\
\text { chy }\end{array}$ & $\begin{array}{l}\begin{array}{l}\text { Emer } \\
\text { ging }\end{array} \\
\text { Indus } \\
\text { trializ } \\
\text { ed } \\
\text { Econ } \\
\text { omy }\end{array}$ & $\begin{array}{l}\text { Camb } \\
\text { odia } \\
\text { borde } \\
\mathrm{r} \\
\text { Issue }\end{array}$ & $\begin{array}{l}\text { Alm } \\
\text { ost } \\
70 \\
\text { ethno } \\
- \\
\text { lingu } \\
\text { istic } \\
\& \\
\text { religi } \\
\text { ous } \\
\text { grou } \\
\text { ps }\end{array}$ \\
\hline $\begin{array}{l}\text { Bru } \\
\text { nei } \\
\text { Dar } \\
\text { ussa } \\
\text { lam }\end{array}$ & $\begin{array}{l}\text { 1 Jan, } \\
1984\end{array}$ & UK & $\begin{array}{l}\text { Unitary } \\
\text { Islamic } \\
\text { absolut } \\
\text { e } \\
\text { Monar } \\
\text { chy }\end{array}$ & $\begin{array}{l}\text { Forei } \\
\text { gn \& } \\
\text { Dom } \\
\text { estic } \\
\text { Entre } \\
\text { prene }\end{array}$ & $\begin{array}{l}\text { Dispu } \\
\text { te on } \\
\text { Spartl } \\
y \\
\text { Islan } \\
\mathrm{d}\end{array}$ & $\begin{array}{l}\text { Heav } \\
\text { y } \\
\text { Ethn } \\
\text { o- } \\
\text { lingu } \\
\text { al \& }\end{array}$ \\
\hline
\end{tabular}




\begin{tabular}{|c|c|c|c|c|c|c|}
\hline & & & & $\begin{array}{l}\text { urshi } \\
\text { p }\end{array}$ & & $\begin{array}{l}\text { religi } \\
\text { ous } \\
\text { diver } \\
\text { sity }\end{array}$ \\
\hline $\begin{array}{l}\text { Viet } \\
\text { nam }\end{array}$ & $\begin{array}{l}2 \\
\text { Sep, } \\
1945\end{array}$ & $\begin{array}{l}\text { Fran } \\
\text { ce }\end{array}$ & $\begin{array}{l}\text { Unitary } \\
\text { Marxis } \\
\text { t- } \\
\text { Leninis } \\
\text { t one- } \\
\text { party } \\
\text { Sociali } \\
\text { st } \\
\text { Republ } \\
\text { ic }\end{array}$ & $\begin{array}{l}\text { Agric } \\
\text { ultura } \\
1 \\
\text { Econ } \\
\text { omy } \\
1986 \\
\text { refor } \\
\text { ms - } \\
\text { Socia } \\
\text { list- } \\
\text { Orien } \\
\text { ted } \\
\text { Mark } \\
\text { et } \\
\text { Econ } \\
\text { omy }\end{array}$ & $\begin{array}{l}\text { Vietn } \\
\text { am } \\
\text { War } \\
\text { Intern } \\
\text { al } \\
\text { Confl } \\
\text { icts }\end{array}$ & $\begin{array}{l}\text { Over } \\
54 \\
\text { ethno } \\
- \\
\text { religi } \\
\text { ous } \\
\text { grou } \\
\text { ps }\end{array}$ \\
\hline $\begin{array}{l}\text { Lao } \\
\text { s }\end{array}$ & $\begin{array}{l}22 \\
\text { Oct, } \\
1953 \\
\text { Mona } \\
\text { rchy } \\
\text { abolis } \\
\text { hed } \\
2 \\
\text { Dec, } \\
1975\end{array}$ & $\begin{array}{l}\text { Fran } \\
\text { ce }\end{array}$ & $\begin{array}{l}\text { Unitary } \\
\text { Marxis } \\
\text { t- } \\
\text { Leninis } \\
\text { t one- } \\
\text { party } \\
\text { Sociali } \\
\text { st } \\
\text { Republ } \\
\text { ic }\end{array}$ & $\begin{array}{l}\text { Inves } \\
\text { tment } \\
\& \\
\text { Trade } \\
\text { based } \\
\text { Econ } \\
\text { omy }\end{array}$ & $\begin{array}{l}\text { Landl } \\
\text { ocked } \\
\text { state } \\
\text { (Civil } \\
\text { War- } \\
1975 \text { ) }\end{array}$ & $\begin{array}{l}\text { Ethn } \\
\text { o- } \\
\text { lingu } \\
\text { al \& } \\
\text { religi } \\
\text { ous } \\
\text { grou } \\
\text { ps } \\
\text { divid } \\
\text { ed in } \\
\text { lowla } \\
\text { nds, } \\
\text { midl } \\
\text { ands } \\
\text { and } \\
\text { highl } \\
\text { ands }\end{array}$ \\
\hline $\begin{array}{l}\mathrm{Ca} \\
\text { mbo } \\
\text { dia }\end{array}$ & $\begin{array}{l}9 \\
\text { Nov, } \\
1953\end{array}$ & $\begin{array}{l}\text { Fren } \\
\text { ch } \\
\text { Prot } \\
\text { ector } \\
\text { ate }\end{array}$ & $\begin{array}{l}\text { Unitary } \\
\text { Domin } \\
\text { ant- } \\
\text { party } \\
\text { Parlia } \\
\text { mentar } \\
\text { y } \\
\text { Electiv } \\
\text { e } \\
\text { Constit } \\
\text { utional } \\
\text { Monar } \\
\text { chy }\end{array}$ & $\begin{array}{l}\text { Agric } \\
\text { ultura } \\
1 \\
\text { (rural } \\
\text { based } \\
\text { ) }\end{array}$ & $\begin{array}{l}\text { Bord } \\
\text { er } \\
\text { Dispu } \\
\text { tes } \\
\text { with } \\
\text { neigh } \\
\text { bors }\end{array}$ & $\begin{array}{l}90 \% \\
\text { Khm } \\
\text { er } \\
\text { (Ethn } \\
\text { o- } \\
\text { lingu } \\
\text { al \& } \\
\text { religi } \\
\text { ous } \\
\text { diver } \\
\text { sity) }\end{array}$ \\
\hline $\begin{array}{l}\text { Mya } \\
\text { nma } \\
\mathbf{r}\end{array}$ & $\begin{array}{l}4 \text { Jan, } \\
1948\end{array}$ & $\begin{array}{l}\text { Brita } \\
\text { in }\end{array}$ & $\begin{array}{l}\text { Unitary } \\
\text { Assem } \\
\text { bly- } \\
\text { Indepe } \\
\text { ndent } \\
\text { Constit } \\
\text { utional } \\
\text { Republ } \\
\text { ic }\end{array}$ & $\begin{array}{l}\text { Smug } \\
\text { gling } \\
\& \\
\text { Illega } \\
1 \\
\text { Trade } \\
\text { Forei } \\
\text { gn } \\
\text { Inves } \\
\text { tment }\end{array}$ & $\begin{array}{l}\text { Intern } \\
\text { al } \\
\text { Confl } \\
\text { icts }\end{array}$ & $\begin{array}{l}68 \% \\
\text { Bam } \\
\text { ar } \\
\text { (Ethn } \\
\text { o- } \\
\text { lingu } \\
\text { al \& } \\
\text { religi } \\
\text { ous } \\
\text { diver } \\
\text { sity) }\end{array}$ \\
\hline
\end{tabular}

Source: Compiled by author from various online web sources (ASEAN, 2020) asean.org.

\section{The Triple-Cs Principle of ASEAN for the Journey of Regional Economic Integration in South-East Asia}

The previous literature on Asian regionalism is mostly influenced with case studies. These case studies primarily focused to build a mechanism of integration for Asian states to opt for the trends of liberal economic order. Because still there exist some illiberal and informal structures which are always questioned when development process is not working according to the desired EU type results. It is also a fact that, most of the accepted initial agreements in SouthEast Asia were designed to provide strategic defense and strengthen the bargaining power of countries in the global political arena, those aims have since expanded to cover various social and economic concerns (UNDP, 2006). So, the experts think out a way to amalgamate the existing patterns with latest economic liberal trends.

Mainly the literary work of Amitav Acharya and Johnston helps to understand the norms which are needed to strengthen the process of integration in Asia. These norms support a pragmatic and flexible policy structure in Asia because it is considered that flexibility of policy structure can better control the issues of diversity with greater sustainability. It is due to the fact that, 'the ASEAN Way reflects, to some extent, the illiberal underpinnings of the Asian values' construct which stresses a communitarian ethic (society over the self) in explaining the region's economic dynamism. This simply refers that in Asia there is a considerable emphasis is on the cultural factors in explaining the ASEAN way and its differences from Europe.'

Besides these the 'ASEAN Way' or soft institutionalism support pragmatism, discreetness, informality, consensusbuilding among regional members and non-confrontational bargaining (to avoid the issues of diversity) style. That's why Katzenstein writes that, regionalism based on ASEAN model is a distinctive form of regional institutionalization compared to Europe (Katzenstein, 1997). ASEAN has undertaken various initiatives to support a market driven economic integration after 1997. Free Trade Agreements used to build closer ties among the members. Further the finance ministers of this grouping initiate a strong financial co-operation with the partnership of ASEAN+3 and they also work to improve their mechanism for regional economic surveillance. ASEAN's Way into the $21^{\text {st }}$ century is dominated by economic interests because it can stimulate the collaboration among the member states of ASEAN despite of their quite distinct political commands ranging from constitutional sultanates to presidential republics. (Arao, 2011).

Keeping in view all these existing norms and the emerging liberal trends of integration, the Triple-Cs principle of ASEAN describes the sense of belonging and consolidated unity that is prevailing in the diversified region of South East Asia. It further describes that how ASEAN works to foster the process of regional integration to achieve Sustainable Development Goals (SDGs). Thus, the Triple- 
Cs Principle is a way forward for the states of the Asian region and specifically for the ASEAN member countries because all these states are included in the group of third world countries or underdeveloped states but regional integration can boost up their capacities to grow rapidly. In the Asian region, two major powers (China and India) possess a good capacity to grow themselves with collaboration, they can help the neighboring states to utilize their capacities in a more beneficial way. But the diversity of cultural values, economic and political structures among them creates hurdles.

To manage these issues ASEAN already working on the policy of Consensus-building among its members. ASEAN members joined that organization and transfer some of their authorities to the organization but still follow their own distinct political and economic structures. According to the experts of Asian regionalism, diversity is a great hurdle in the integration process of the region while its integration is crucial for the rapid growth of the region. This paper analyzes that how ASEAN accentuates the process of integration in the South East Asian region in spite of its diversity.

\section{Triple-Cs}

C Commitment to regional growth

C Co-operation among regional entities

C Connectivity as an effective mode to regional economic integration

The diversity of the Asian region is deep-rooted but, in spite of it, each state is interested in its socio-economic development. In this interdependent world, no state can achieve this goal by being isolated. So, there is a dire need to adopt collective actions on a regional level to get the goal of socio-economic development. Although the feature of conflict will remain in this region due to deep ethnopolitical diversity but co-operation is inevitable for the progress of the whole region. The modes of cooperation may vary according to the need of the time but a commitment to cooperation is a key to keep the regional entities (states) connected with each other for the sake of regional prosperity.

The new trends of globalization inclined them to focus on people to people contact in this regard. This policy of people-to-people contact has increased the ratio of crossborder private businesses and cultural exchange. Digital technology has made this idea more viable and the level of connectivity has increased rapidly through available facilities of e-commerce. All these features of the Triple-Cs principle combined lead this region towards socio-economic development. Further, it will improve the peace, progress, and prosperity index of regional states. Because it is a wellknown fact that, 'commercially benefitted borders can reduce the chances of conflict'. So, these principles will also be helpful to maintain peace in the region.

The Triple-Cs principle explains the ASEAN's journey of regional integration. It explains extensively that how ASEAN preserved its unity among its diversified regional states. ASEAN is an intergovernmental organization which only takes decision until and unless it reaches on a consensus. In this way, ASEAN watches the interest of each member state (Jetin, 2017). In fact, Commitment to cooperation in the socio-economic sector to eradicate poverty and improve the human development index is a consistent feature of ASEAN since its inception. For that purpose, initially, it promoted security balance among member states. It was considered that time that peace could lead the region towards collaboration in regional economic development.

Later, they changed their view and decided to liberalize their economic and trade policies keeping the existing ethnopolitical conflicts aside. The rationale behind that move was when goods do not move the border then soldiers do. So, free trade and cross-border business opportunities would change the public opinion regarding certain political conflicts among states and public opinion will create pressure on their respective states to avoid engaging in physical conflicts that may create warlike situations and undermine their cross-border commercial interests.

Hence, ASEAN shifted its mode of cooperation from 'peace before trade' to ' peace through trade'. And decided to liberalize trade practices within the region. That close regionalism policy could not succeed to get the expected output. Later, the policy of close regionalism was replaced with open regionalism. ASEAN as a single economic group signed free trade agreements with different countries i.e., Japan, Korea, China, India, Australia, and New Zealand. The reason behind these agreements was the commitment to deeper integration for wider coverage. The inclusion of ASEAN+1 free trade agreement (FTAs) was an indication that now ASEAN had become a forum of open regionalism (Das, 2016).

The concepts of ASEAN+ widened from ASEAN+ 1 to ASEAN+3, and ASEAN+6 all are introduced to get access to new larger markets for regional development. All of this could become possible due to ASEAN's commitment to increase their Connectivity for the prosperous region despite their diverse political systems. The members of the organization consider it an opportunity for increasing their links with the other states. Das (2016) defines that the journey of connectivity began with the establishment of the ASEAN Free Trade Area in 1992, followed by the ASEAN Economic Community in 2003 and then the shift to ASEAN Connectivity in 2010' (Das, 2016). Further, the induction of observer states in ASEAN is also the reason for increasing the intra-regional and inter-regional connectivity. Through this, the member states are willing to cover those areas where one state is lacking its capacity to develop and the other is strong. The connection between the regional states can fill this gap easily and the regional dependency on other regions will be reduced.

Many scholars support this point of view that ASEAN started its journey as a regional organization to achieve the objective of regional security and peace but it shifted to regional economic integration in 1992, with the creation of AFTA (ASEAN Free Trade Area). According to this agreement, the member countries of ASEAN decided to lower down the tariffs within the region to 0-5\%. Soon after this, it was followed by the AFAS in 1995 (ASEAN Framework Agreement on Services) and AIA (ASEAN Investment Area) in 1998. However, for economic integration ASEAN decided to adopt a comprehensive approach which is AEC (ASEAN Economic Community) in 2003. This ASEAN Economic Community (AEC) is further 
having two more simultaneous pillars named APSC (ASEAN Political-Security Community) and ASCC (ASEAN Socio-Cultural Community). These communities of AEC worked for the peace, stability, and co-operation in education, social security, natural disaster, pandemics, and deciding about measures that are important for the general growth and made continuous efforts for the sustainable development of these countries (Das, 2016).

Table 2: Comparison between 2010 and 2020 in selected key indicators of ASEAN Member States

\begin{tabular}{|c|c|c|c|c|c|c|c|c|c|c|c|c|}
\hline \multicolumn{13}{|c|}{ Selected Key Indicators of ASEAN Member States (2010-2020) } \\
\hline \multirow{3}{*}{ Country } & \multicolumn{2}{|c|}{ Economy } & \multicolumn{4}{|c|}{ Trade } & \multicolumn{2}{|c|}{ Investment } & \multirow{2}{*}{\multicolumn{2}{|c|}{$\begin{array}{l}\text { Socio- } \\
\text { Demography } \\
\text { Unemployment } \\
\text { Rate }\end{array}$}} & \multirow{2}{*}{\multicolumn{2}{|c|}{$\begin{array}{l}\text { Connectivity } \\
\text { Internet } \\
\text { subscribers }\end{array}$}} \\
\hline & \multicolumn{2}{|c|}{$\begin{array}{l}\text { Rate of } \\
\text { Economic } \\
\text { Growth \% }\end{array}$} & \multicolumn{2}{|c|}{$\begin{array}{l}\text { Trade in } \\
\text { goods }\end{array}$} & \multicolumn{2}{|c|}{$\begin{array}{l}\text { Trade in } \\
\text { services } \\
\text { (Exports) }\end{array}$} & \multicolumn{2}{|c|}{$\begin{array}{ll}\text { (FDI) } & \text { Inward } \\
\text { Flows } & \end{array}$} & & & & \\
\hline & 2010 & 2020 & 2010 & 2020 & 2010 & 2020 & 2010 & 2020 & 2010 & 2020 & 2010 & 2020 \\
\hline $\begin{array}{l}\text { Brunei } \\
\text { Darussalam }\end{array}$ & 2.6 & 3.9 & $\begin{array}{l}11,27 \\
4.2\end{array}$ & $\begin{array}{l}12, \\
141.8\end{array}$ & 460.5 & 617.9 & 625.4 & 625.4 & 17.9 & 16.2 & 49.0 & 95.0 \\
\hline Cambodia & 6.0 & 7.1 & $\begin{array}{l}8,601 \\
.2\end{array}$ & $\begin{array}{l}34,58 \\
0.2\end{array}$ & $\begin{array}{l}2,028 \\
.5\end{array}$ & $\begin{array}{l}6,086 \\
.3\end{array}$ & 782.6 & $\begin{array}{l}3,663 \\
.0\end{array}$ & 27.5 & N/A & 1.3 & 40.5 \\
\hline Indonesia & 6.2 & 5.0 & $\begin{array}{l}293,4 \\
42.4\end{array}$ & $\begin{array}{l}338,9 \\
58.7\end{array}$ & $\begin{array}{l}16,67 \\
0.5\end{array}$ & $\begin{array}{l}31,64 \\
4.8\end{array}$ & $\begin{array}{l}13,770 . \\
2\end{array}$ & $\begin{array}{l}23,94 \\
3.2\end{array}$ & $8,319.8$ & $\begin{array}{l}7,045 \\
.8\end{array}$ & 10.9 & 47.7 \\
\hline Lao PDR & 8.1 & 6.4 & $\begin{array}{l}3,745 \\
.4\end{array}$ & $\begin{array}{l}11,60 \\
6.8\end{array}$ & 511.0 & $\begin{array}{l}1,179 \\
.2\end{array}$ & 332.6 & 755.5 & 805.4 & N/A & 7.0 & 25.5 \\
\hline Malaysia & 7.4 & 4.4 & $\begin{array}{l}363,2 \\
34.4\end{array}$ & $\begin{array}{l}443,0 \\
13.8\end{array}$ & $\begin{array}{l}34,50 \\
9.5\end{array}$ & $\begin{array}{l}40,98 \\
8.1\end{array}$ & $9,155.9$ & $\begin{array}{l}7,698 \\
.0\end{array}$ & 404.5 & 508.2 & 56.3 & 84.2 \\
\hline Myanmar & 9.6 & 6.2 & $\begin{array}{l}11,86 \\
6.6\end{array}$ & $\begin{array}{l}36,57 \\
5.0\end{array}$ & 376.8 & $\begin{array}{l}6,662 \\
.8\end{array}$ & $2,248.8$ & $\begin{array}{l}1,729 \\
.9\end{array}$ & $1,240.0$ & N/A & 0.1 & 33.1 \\
\hline Philippines & 7.3 & 6.0 & $\begin{array}{l}109,6 \\
60.3\end{array}$ & $\begin{array}{l}188,3 \\
01.3\end{array}$ & $\begin{array}{l}17,78 \\
2.0\end{array}$ & $\begin{array}{l}40,97 \\
3.6\end{array}$ & $1,298.0$ & $\begin{array}{l}7,685 \\
.3\end{array}$ & $2,859.0$ & $\begin{array}{l}2,263 \\
.9\end{array}$ & 4.6 & 70.7 \\
\hline Singapore & 15.2 & 0.7 & $\begin{array}{l}666,3 \\
18.1\end{array}$ & $\begin{array}{l}749,9 \\
53.0\end{array}$ & $\begin{array}{l}100,3 \\
83.1\end{array}$ & $\begin{array}{l}204,8 \\
07.4\end{array}$ & $\begin{array}{l}57,460 . \\
6\end{array}$ & $\begin{array}{l}92,07 \\
8.2\end{array}$ & 64.8 & 72.8 & 48.9 & 88.9 \\
\hline Thailand & 7.5 & 2.4 & $\begin{array}{l}376,2 \\
25.3\end{array}$ & $\begin{array}{l}483,2 \\
49.1\end{array}$ & $\begin{array}{l}34,33 \\
9.8\end{array}$ & $\begin{array}{l}81,99 \\
4.2 \\
\end{array}$ & $\begin{array}{l}14,746 . \\
7\end{array}$ & $\begin{array}{l}14,74 \\
6.7 \\
\end{array}$ & 402.2 & 373.4 & 22.4 & 66.7 \\
\hline Vietnam & 6.4 & 7.0 & $\begin{array}{l}157,0 \\
75.2 \\
\end{array}$ & $\begin{array}{l}518,0 \\
52.4 \\
\end{array}$ & $\begin{array}{l}7,459 \\
.7 \\
\end{array}$ & $\begin{array}{l}29,82 \\
4.9 \\
\end{array}$ & $8,000.0$ & $\begin{array}{l}16,12 \\
0.0 \\
\end{array}$ & $1,344.0$ & $\begin{array}{l}1,106 \\
.0 \\
\end{array}$ & 34.5 & 68.7 \\
\hline$A S E A N$ & 7.5 & 4.7 & $\begin{array}{l}2,001 \\
443 \\
0\end{array}$ & $\begin{array}{l}2,816 \\
, 432 . \\
0\end{array}$ & $\begin{array}{l}214,5 \\
21.5\end{array}$ & $\begin{array}{l}444,7 \\
79.1\end{array}$ & $\begin{array}{l}108,42 \\
0.7\end{array}$ & $\begin{array}{l}158,8 \\
64.4\end{array}$ & N/A & N/A & 18.7 & 57.0 \\
\hline
\end{tabular}

Source: ASEAN Statistical Yearbook 2020, available on: https://www.aseanstats.org/

All of these piecemeal efforts of ASEAN indicated that it brought necessary changes in modes of regional cooperation from time to time but it continued to move forward and grow continuously without bothering about the failures. In the first decade of the 21 st century, ASEAN continued its journey of integration through connectivity and introduced Master Plan for ASEAN Connectivity (MPAC). This program of connectivity is based on three main elements i.e., institutional connectivity, physical connectivity, and people-to-people connectivity (see the table below). According to this plan, both countries expected to increase transport connectivity as a way to bring member or participating countries closer to one another, facilitating better access for trade, investment, tourism, and people-topeople exchange (Pitlo III, 2015). But the obstacles to the implementation of the AMPC include the policy and institutional barriers that have not been reduced. Rules, regulations, and standards have not been harmonized between AMS. (Jetin, 2017).
After the inclusion of more states in ASEAN the network for connectivity increased to more sectors. ASEAN has set some goals for more connectivity and announced the plan of regional integration, named AEC 2025. In this plan, the previous commitments are retained but ideas and headings replaced with new words like people-oriented and good governance. In September 2016, a document of ASEAN Connectivity mentions that both 'hard and soft' infrastructure is needed to strengthen and to sustain the process of regional economic integration. Infrastructure is quite important to promote the rapid growth of the groups, communities and region because even landlocked states got routes to the international markets. "Physical connectivity through cross-border Infrastructure development is crucial for enhanced regional co-operation and economic integration" (Bhattacharyay, 2010). However, in 2010s ASEAN worked on multiple programs of connectivity to enhance the integration among the diversified region. The table given below describes the ASEAN's plan of future connectivity. 
Table 3: ASEAN's Master Plan of Regional Connectivity

\begin{tabular}{|c|c|c|c|c|}
\hline \multicolumn{5}{|c|}{ ASEAN CONNECTIVITY 2025} \\
\hline $\begin{array}{l}\text { Sustainable } \\
\text { Infrastructure }\end{array}$ & Digital Innovation & $\begin{array}{l}\text { Seamless } \\
\text { logistics }\end{array}$ & $\begin{array}{l}\text { Regulatory } \\
\text { Excellence }\end{array}$ & People Mobility \\
\hline \multicolumn{5}{|c|}{ STRATEG I C OB JECTIVES } \\
\hline $\begin{array}{l}\text { - As per need } \\
\text { of each ASEAN } \\
\text { member states, } \\
\text { investment of the } \\
\text { public and private } \\
\text { infrastructure will be } \\
\text { increased. } \\
\text { - To enhance } \\
\text { its evaluation } \\
\text { capacity and the } \\
\text { infrastructure } \\
\text { productivity in } \\
\text { ASEAN member } \\
\text { countries. The models } \\
\text { - smart } \\
\text { of in all } \\
\text { urbanization will be } \\
\text { deployed in member } \\
\text { ASEAN in mates. } \\
\text { state }\end{array}$ & $\begin{array}{l}\text { - Technolog } \\
\text { y will be adopted } \\
\text { through MSMEs } \\
\text { (Micro, small and } \\
\text { Medium } \\
\text { enterprises) } \\
\text { - Financial } \\
\text { access will be } \\
\text { made easy through } \\
\text { digital technology } \\
\text { - In the } \\
\text { member states of } \\
\text { ASEAN use of } \\
\text { open data will be } \\
\text { improved and } \\
\text { support enhance } \\
\text { data management }\end{array}$ & $\begin{array}{l}\text { - To lower } \\
\text { the costs of } \\
\text { supply chains in } \\
\text { the member states } \\
\text { To } \\
\text { improve the } \\
\text { reliability and } \\
\text { speed of the } \\
\text { supply chains }\end{array}$ & $\begin{array}{l}\text { - ASEAN } \\
\text { members mutually } \\
\text { recognize the } \\
\text { standards of } \\
\text { products and } \\
\text { technical regulations } \\
\text { in their key sectors } \\
\text { - The } \\
\text { member states of } \\
\text { ASEAN will reduce } \\
\text { the number of non- } \\
\text { tariff measures } \\
\text { which distort the } \\
\text { trade activities. }\end{array}$ & $\begin{array}{l}\text { - Travelling make } \\
\text { easy across the ASEAN } \\
\text { - To fill the gaps } \\
\text { between the demand and } \\
\text { supply of vocational } \\
\text { skills' throughout } \\
\text { ASEAN } \\
\text { - Increase the } \\
\text { number of intra-ASEAN } \\
\text { educational scholarships } \\
\text { for students }\end{array}$ \\
\hline $\begin{array}{lllllll}\text { I } & \mathbf{N} & \mathbf{I} & \mathbf{T} & \mathbf{I} & \mathbf{A} & \mathbf{T} \\
\end{array}$ & $\begin{array}{lll}\mathrm{N} \\
\end{array}$ & & & \\
\hline $\begin{array}{l}\text { - To give } \\
\text { priority to establish } \\
\text { soft and hard } \\
\text { infrastructure in } \\
\text { ASEAN. } \\
\text { - To } \\
\text { establish a platform } \\
\text { to improve and } \\
\text { measure the } \\
\text { infrastructure } \\
\text { productivity. } \\
\text { - To develop } \\
\text { the strategies of } \\
\text { sustainable } \\
\text { urbanization in the } \\
\text { cities of ASEAN. }\end{array}$ & $\begin{array}{lr}\text { - } & \text { Technolog } \\
\text { y Platforms for } \\
\text { MSME will be } \\
\text { enhanced. } \\
\text { - ASEAN } \\
\text { developed } & \text { the } \\
\text { framework } & \text { of } \\
\text { digital financial } \\
\text { inclusion } \\
\text { - Open data } \\
\text { network } & \text { for } \\
\text { ASEAN } & \text { is } \\
\text { established } \\
\text { - A r } \\
\text { framework } \\
\text { digital of } \\
\text { governance rata } \\
\text { established } \\
\text { ASEAN in }\end{array}$ & $\begin{array}{l}\text { - To } \\
\text { enhance the trade } \\
\text { routes and } \\
\text { logistics ro } \\
\text { strengthen the } \\
\text { competitiveness } \\
\text { of ASEAN } \\
\text { - To } \\
\text { enhance the } \\
\text { efficiency of } \\
\text { Supply chains by } \\
\text { addressing } \\
\text { stoppages. }\end{array}$ & $\begin{array}{l}\text { - In the } \\
\text { prioritized sectors of } \\
\text { product groupings, a } \\
\text { harmonization of } \\
\text { mutual recognition, } \\
\text { accepted standards, } \\
\text { and technical } \\
\text { regulations is } \\
\text { maintained. } \\
\text { - increased } \\
\text { transparency and } \\
\text { methods } \\
\text { evaluation } \\
\text { introduced } \\
\text { minimize the non- } \\
\text { tariff trade distorting } \\
\text { measures }\end{array}$ & $\begin{array}{l}\text { - Easy } \\
\text { information of finding } \\
\text { make travel easier } \\
\text { throughout the ASEAN } \\
\text { - Enhanced } \\
\text { facilities regarding visa } \\
\text { processes to make travel } \\
\text { easy According to } \\
\text { - } \\
\text { the needs of each } \\
\text { ASEAN member state, } \\
\text { establishment of } \\
\text { common standard of } \\
\text { qualifications and } \\
\text { vocational training } \\
\text { programs for } \\
\text { - } \\
\text { exchange of higher } \\
\text { education throughout } \\
\text { ASEAN }\end{array}$ \\
\hline
\end{tabular}

Source: Compiled by researcher from online resources \& reports (MPAC, 2016) \& (AEIB, 2019)

\section{Phases of Transition to maintain Connectivity}

Phase one started from the establishment of ASEAN in 1967. Initially, this organization worked at a slow pace because of the intense relations between the regional entities during the cold war. During this phase, framers of this organization mainly concentrated on the maintenance of peace and regional harmony, but the concentration on economic co-operation was minimal. In 1971, the establishment of the Zone of Peace, Freedom, and Neutrality (ZOPFAN) accentuate the process of harmony and also inclined the members to avoid their conflicts for the broader and common interest of regional development. In 1974, a Kansu report by the UN, suggest the policies of selective trade liberalization, financial co-operation, and product-byproduct tariff negotiations to ASEAN, and after this many committees worked on these suggestions and found further areas to collaborate in the future.

Phase two starts with more active action policies to work for the regional development. ASEAN Preferential Trading Agreement (APTA) [considered a more encouraging policy for intra-ASEAN trade through institutional integration and regional trade preferences], ASEAN Industrial Projects (AIPs), ASEAN Industrial Complementation (AIC), and ASEAN Industrial Joint Ventures (AIJVs) opted for regional 
co-operation. Although these initiatives brought limited success due to the unwillingness and unpreparedness of the member states but helped ASEAN to be recognized as one unit on the international forums. Despite this limited achievement ASEAN swiftly continued its efforts to enhance strong regional connections. This phase actually worked to enhance the self-confidence of the ASEAN states in the region by managing to escape from the mid-1980s debt crisis.

Phase three ushered with new and vibrant dimensions of connectivity to move on for ASEAN. In 1992, ASEAN Free Trade Area (AFTA) was announced and for the first time in the history of ASEAN, the policy of free trade was adopted as a regional objective and a timeline is also decided to meet the goals. The leaders of all ASEAN members states' decision to reduce the Common Effective Preferential Tariff (CEPT) rates from 0-5\% till 2008. Along with it, leaders of member states also decided that up-till 2000, $85 \%$ of tariff lines and by $2001,90 \%$ will be in the inclusion list. This phase initiated with great enthusiasm but ended with great criticism about ASEAN. The events like Asian Financial Crisis 1997, the Timor crisis, Forest Fires, and Regional Haze Pollution exposed the feeble and ineffective policies of ASEAN regarding responsive measures to such incidents. Due to this, the region lost its commercial attractiveness as well. So, the leaders decided to reconsider the policies of coordination and co-operation to enhance their capacity to macroeconomic responses for future hazards.

The fourth phase is marked with great significant changes in the ASEAN. The start of the 21 st century was multi-polar hegemonic as China had emerged as a potential global hegemon. During that phase, ASEAN was boldly working on the spread of Preferential Trade Agreements among its member states. ASEAN worked hard to enhance its response capacity and co-ordination to handle post-crisis macroeconomic issues. It also adopted the policies of trade liberalization and the goal of intra-regional trade expanded to inter-regional trade activities. ASEAN +3 is the most significant step of this phase. Further, it adopted the policies of 'fragmentation trade' also known as trade-in parts, which lead the ASEAN member states to rapid growth and became a dominant player of the East Asian region. Further, ASEAN introduced a Master Plan for ASEAN Connectivity (MPAC) in 2010 to enhance its connectivity with regional entities and its impact on international forums.

To achieve its vision, the Master Plan for ASEAN Connectivity (MPAC 2025) outlines five strategic areas, namely, sustainable infrastructure, digital innovation, seamless logistics, regulatory excellence, and people mobility. These five areas are deemed key to enhancing physical, institutional, and people-to-people connectivity (Maria, 2018). Many of the world ranking organizations like World Bank, measure the growth of ASEAN Connectivity for better development. For instance, "The indicators and economic models show a number of policy areas that have progressed well. Significant improvements were observed, particularly for process-oriented and institutional measures related to transnational trade and people mobility. There has been a significant increase in land crossings in Thailand, Laos and Cambodia, for instance, and the many ASEAN Member States have experienced appreciably increasing scores on indices like Trading Across Borders" (Connectivity, 2016).

Table 4: A Journey towards Regional Economic Integration (1967- 2020)

\begin{tabular}{|c|c|}
\hline Chronology of Events & Explanation \\
\hline $\begin{array}{l}\text { Establishment of ASEAN on } \\
8^{\text {th }} \text { August, } 1967\end{array}$ & $\begin{array}{l}\text { For strategic and security concerns, the Five countries of South East Asia } \\
\text { established the supranational intergovernmental organization for regional } \\
\text { cooperation to prevent inter-state conflicts between the member states. }\end{array}$ \\
\hline $\begin{array}{l}\text { Declaration of ASEAN } \\
\text { Concord, also known as the } \\
\text { Bali Concord } 1 \text { (1976) in } \\
\text { Bali on 23-24 February, } \\
1976\end{array}$ & $\begin{array}{l}\text { Treaty of Amity and Cooperation (TAC) was formalized during the First ASEAN } \\
\text { Summit in Bali in February 1976. The treaty legally binds all its ASEAN } \\
\text { signatories for peaceful co-existence, respect for the principles of sovereignty, } \\
\text { territorial integrity, non-interference in internal affairs, and non-use of force (these } \\
\text { rules are enshrined in 'ASEAN Way'- the official anthem of ASEAN). }\end{array}$ \\
\hline Development in 1970 s & 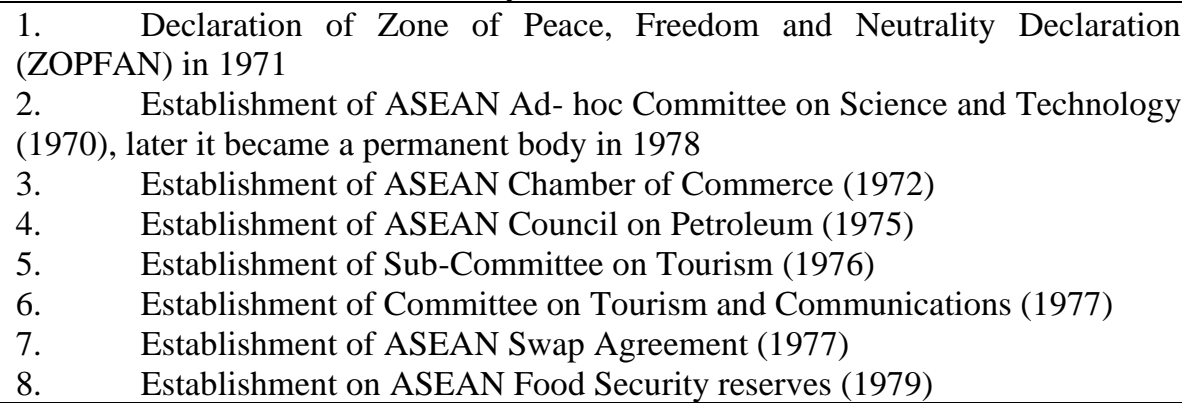 \\
\hline Developments in 1980s & $\begin{array}{ll}\text { 1. } & \text { Brunei Darussalam joins ASEAN 7 January, } 1984 \\
\text { 2. } & \text { Plaza Accord (September, 1985) } \\
\text { 3. } & \text { Manila Declaration on 15 December } 1987 \\
\end{array}$ \\
\hline Developments in 1990s & $\begin{array}{ll}\text { 1. } & \text { AFTA/CEPT launched on 28 January, } 1992 \\
\text { 2. } & \text { ASEAN Declaration on the South China Sea, Manila, 22 July } 1992 \\
\text { 3. } & \text { ASEAN Framework Agreement on Services (AFAS) was signed in } 1995 \\
\text { 4. } & \text { Vietnam Joins in 28 July, 1995 } \\
\text { 5. } & \text { ASEAN plus Three (China, Japan and Korea) joins in } 1997 \\
\text { 6. } & \text { Lao PDR and Myanmar join on 23 July, 1997 } \\
\text { 7. } & \text { 1997 Asian Financial Crisis }\end{array}$ \\
\hline
\end{tabular}




\begin{tabular}{|c|c|}
\hline & $\begin{array}{l}\text { 8. The crisis prompted ASEAN to accelerate regional financial cooperation. } \\
\text { 9. Treaty on the Southeast Asia Nuclear-Weapon-Free Zone, Bangkok, } 15 \\
\text { December } 1997 \\
\text { 10. ASEAN Vision 2020, Kuala Lumpur, } 15 \text { December } 1997 \\
\text { 11. ASEAN Framework on Mutual Recognition Arrangements (MRAs), } \\
\text { signed in } 1998 \\
12 \text { ASEAN finance ministers formalized the ASEAN Surveillance Process } \\
\text { (ASP) which served as a framework for closer consultations on economic policies } \\
\text { on October, } 1998 \\
\text { 13. Cambodia joins on } 30 \text { April, } 1999 \\
\text { By 1999, the region achieved the ASEAN-10 vision by comprising all } 10 \text { countries } \\
\text { in the region and ASEAN plus Six had been initiated as well. }\end{array}$ \\
\hline Developments in 2000s & $\begin{array}{l}\text { ASEAN +3 announce Chiang Mai Initiative on 6-8 May } 2000 \\
\text { Bali Concord II of } 2003 \\
\text { ASEAN Economic Community launched on } 7 \text { October, } 2003 \\
\text { AEC Blueprint } 2015 \text { launched in } 2007 \\
\text { Expanded CMI launched on } 22 \text { February, } 2009\end{array}$ \\
\hline Developments in 2010s & $\begin{array}{ll}\text { 1. } & \text { Master Plan for ASEAN Connectivity (2010) } \\
\text { 2. } & \text { The Chiang Mai Initiative Multilateralization Agreement (2010) } \\
\text { 3. } & \text { The ASEAN Financial Integration Framework (2011) } \\
\text { 4. } & \text { The ASEAN Insurance Integration Framework (2011) } \\
\text { 5. } & \text { The Capital Account Liberalization Heat Map (2013) } \\
\text { 6. } & \text { The ASEAN Banking Integration Framework (2014) } \\
\text { 7. } & \text { The ASEAN Capital Market Infrastructure Blueprint (2014) } \\
\text { 8. } & \text { Establishment of ASEAN Economic Community (AEC) in 2015 }\end{array}$ \\
\hline
\end{tabular}

Source: Compiled by researcher data extracted from (AECD, 2017) \& (ASEAN, 2019)

\section{Conclusion}

Regional integration in Asia is considered mandatory for the development of the region by many scholars. Asian regionalism is the goal that is helpful to accelerate the overall process of development in the region. ASEAN is considered the most enduring organization in the Asian region and it consistently continued its piecemeal efforts for regional integration since its initiation. During this journey of integration, Sometimes, ASEAN failed to cope with some issues but it never gave up its efforts for regional integration. However, to achieve its goal of Regional integration, ASEAN proceeded ahead and passed through many dimensions and changes in its scope of policy and institutional functioning. In addition, changes in patterns, policies, and means to achieve their targets had also been visible with time. But one thing was constant, i.e., the ASEAN's commitment to continue regional cooperation through enhancing the level of connectivity among its member states. In the 21 st century, after the revolution in the communication industry, through digital means, regional connectivity has been accentuated significantly.

The above-mentioned Triple-Cs principle best analyzes the journey of ASEAN's regional connectivity. ASEAN's commitment to regional cooperation through connectivity remarkably improved the macroeconomic indicators of the regional entities(states). Today ASEAN has become a highly competitive economy of the world and has become a world-class investment destination. It attracted US\$ 97 billion in Foreign Direct Investment in 2016, 80\% of which was in the service sector. (AECD, 2017) The ASEAN highway network (AHN) runs 38,400 km through 10 ASEAN member states and the seating capacity of flights to and from ASEAN has more than doubled due to increasing in intra-regional tourism and FDI. Digital connectivity has been threefold during the last decade.

After the adoption of the 'open regionalism' policy, China's inclusion in ASEAN paved the way for more Connectivity in possible sectors. Some scholars consider the trends of economic liberalization and co-operation as the software while connectivity as hardware to the regional integration. So, the connectivity has become the most crucial to gain the profits of trade and investment from regional integration. China is using physical connectivity as a means to boost up its economy but ASEAN countries are still hesitant to do so. However, China can play a great role in improving ASEAN's connectivity network. In addition to this, ChinaASEAN Free Trade Area (CAFTA) offers a favorable environment for ASEAN to take a lead in peace, prosperity, and integration in South-East Asia.

For these benefits, physical connectivity (through rails, roads, and sealines) and digital connectivity (through ecommerce) is considered necessary to reduce cross-border business transaction costs, time consumption, and travel costs. Further, it will be beneficial for the core and peripheral areas of ASEAN member countries. It will ultimately reduce the development gaps among the member states and evenly increase prosperity among member states

\section{References}

[1] Acharaya, A. (2004). How Ideas Spread: Whose Norms Matter? Norm Localization and Institutional Change in Asian Regionalism. The UW - Journals Division, 239-275. 
[2] Acharaya, A. (2007). Culture, security, multilateralism: The 'ASEAN way' and regional order. Contemporary Security Policy, 55-84.

[3] ADB. (2020). Asia'a Journey to Prosperity: Policy, Market and Technology over 50 Years. Phillipines: Asian Development Bank.

[4] AECD. (2017). A Journey Towards Regional Economic Integration: 19672017. Jakarta: ASEAN Economic Community Department.

[5] AEIB. (2019). ASEAN Economic Integration Brief. Jakarta: ASEAN Secretariate.

[6] Arao, M. L. (2011). The ASEAN Guide: A Journalist's Handbook to Regional Integration in Southeast Asia. Germany: GIZ institute.

[7] ASEAN. (2019, March 26). Association of Southeast Asian Nations (ASEAN). Retrieved from NTI: https://www.nti.org/learn/treaties-andregimes/association-southeast-asiannationsasean/\#: :text=ASEAN\%20was\%20establ ished $\% 20$ on $\% 208$,Cambodia $\% 20$ on $\% 2030$ $\% 20$ April\%201999.

[8] ASEAN. (2020, September 02). ASEAN. Retrieved from ASEAN: A Community of Opportunities for all: https://asean.org/asean-economiccommunity/

[9] Bhattacharyay, B. N. (2010). Infrastructure for ASEAN Connectivity and Integration. ASEAN Economic Bulletin, 200-220.

[10] Brozel, T. A. (2016). The Oxford Handbook of Comparative Regionalism. UK: Oxford university press.

[11] Brozel, T. A. (2016). Theorizing Regonalism: Co-operation, integration and Governance. In T. A. Risse, A Handbook of Comparative Regionalism (pp. 41-63). New York: Oxford University Press.

[12] Connectivity, A. (2016). Enhancing ASEAN Connectivity Monitoring and Evaluation. Jakarta: The World Bank and
ASEAN Connectivity Co-ordinating Committee.

[13] Das, S. B. (2016). ASEAN's Regional Integration will be Determined by Better Connectivity in the Future. ISEAS Perspective, 1-10.

[14] Guan, B. T. (2004). ASEAN's Regional Integration Challenge: The ASEAN Process. The Copenhagen Journal of Asian Studies, 70-94.

[15] Jetin, B. (2017). "One Belt-One Road Initiative" and ASEAN Connectivity: Synergy Issues and Potentialities". Institute of Asian Studies, 1-19.

[16] Kahler, M. (1994). Institutiona Building in the Pacific. In A. M. Ravenhill, In Pacific Co-operation: Building Economic and Security Regimesin the Asia Pacific Region (pp. 16-39). Australia: Allen \& Unwin.

[17] Katzenstein, P. (1997). Introduction: Asian Regionalism in Comparative Perspective. In P. K. Shiraishi, Network Power: Japan and Asia (pp. 1-44). New York: Cornell University Press.

[18] Maria, D. R. (2018, September). ASEAN CONNECTIVITY: FROM RHETORIC TO REALITY. Retrieved from ALUMNUS:

https://www.nus.edu.sg/alumnet/thealumn us/issue-114/perspectives/panorama/aseanconnectivity-from-rhetoric-to-reality

[19] McVey, R. (1995). Change and Continuity in Southeast Asian Studies. Journal of Southeast Asian Studies, 1-9.

[20] MPAC, A. (2016). Master Plan on ASEAN Connectivity 2025. Jakarta: ASEAN Secratariate.

[21] Park, B. H. (2017). The Evolution of the "ASEAN Way": Embracing Human Security Perspectives. Asia-Pacific Social Science Review, 1-15.

[22] Phan Thanh Chung, S. S. (2019). How Does FInancial Development Interact with Economic Growth in Five ASEAN Countries. The Singapore Economic Review, 441-460. 
[23] Pitlo III, L. B. (2015, March 26). The Diplomats/Economy. Retrieved August 13, 2020, from The Diplomats: https://thediplomat.com/2015/03/aseanconnectivity-and-chinas-one-belt-oneroad/

[24] Soderbaum, F. (2011). Theories of Regionalism. Routledge, 1-22.

[25] Soong, J. J. (2018). China's One Belt and One Road Initiative Meets ASEAN Economic Community: Propelling and Deepening Regional Economic Integration? The Chinese Economy, 291297.

[26] Stone, E. Z. (2018). ASEAN Think Tanks, Policy Change and Economic Cooperation: From the Asian Financial Crisis to the GLobal FInancial Crisis. Policy and Society, 260-275.

[27] Tan, S. S. (2019). Not Quite Beyond the 'ASEAN Way'? Southeast Asia's Evolution to Rules-based management of Intra-ASEAN Differences. ASEAN@50, 67-87.

[28] Tekunan, S. (2014). The ASEAN Way: The way to Regional Peace. Journal Hubangan Internasional, 142-147.

[29] UNDP. (2006). South East Asia Regional Economic Integration and Co-operation. Colombo: Human Development Report Unit.

[30] Wikipedia. (2020, September 02). Wikipedia. Retrieved from Wikipedia: https://en.wikipedia.org/wiki/ASEAN

[31] Wikipedia. (2020, September 02). Wikipedia. Retrieved from Wikipedia: https://en.wikipedia.org/wiki/Ethnic_group s_of_Southeast_Asia 